\title{
Application of Ice Induction Method Using Silver lodide to Cryopreservation of Bovine Embryos
}

\author{
Toshiyuki Kojıma, Tadashi Soma and Norihiko OgurI \\ Department of Animal Reproduction, National Institute of Animal Industry \\ Tsukuba-Norindanchi, P.O. Box 5, Ibaraki, 305 JAPAN
}

(Accepted for publication March 13, 1987)

\begin{abstract}
Summary. In our previous study we have reported a new method for inducing ice crystal formation in extracellular solution using silver iodide. Rabbit morulae survived freezing with the silver iodide seeding method. The present study examined the viability of frozen bovine embryos using the silver iodide seeding procedure after transfer to appropriate heifers.

Seven-days excellent and good embryos recovered from superovulated heifers by FSH were used in the present study. Plastic straws were used for frozen storage of the embryos. Each straw was filled by successive aspiration of the following fractions: $70 \mathrm{~mm}$ high of $10 \% \mathrm{v} / \mathrm{v}$ glycerol containing one embryo, $3 \mathrm{~mm}$ of air and $10 \mathrm{~mm}$ of $1 \%$ suspension of silver iodide in distilled water (Fig. 1). The straws were cooled to $-7^{\circ} \mathrm{C}$ at $1^{\circ} \mathrm{C} / \mathrm{min}$, and held at $-7^{\circ} \mathrm{C}$ for $10 \mathrm{~min}$ without initiating seeding. They were then cooled to $-35^{\circ} \mathrm{C}$ at $0.3^{\circ} \mathrm{C} / \mathrm{min}$ and plunged into liquid nitrogen. After rapid thawing, the embryos recovered were immersed in $0.75 \mathrm{M}$ or $1.0 \mathrm{M}$ sucrose solution for $10 \mathrm{~min}$ and washed by modified phosphate buffered saline solution. The seven embryos were transferred to the total 7 recipients synchronized. This resulted in two pregnant cows which delivered male normal calf, respectively. KEY WORDS; SEEDINs, SILVER IODIDE, ICE INDUCTION, CRYOPRESERVATION OF BOVINE EMBRYOS.
\end{abstract}

Jpn J Anim Reprod 33, 73-76, 1987

\section{ヨウ化銀による氷晶形成誘起法の牛肧凍結保存への応用}

\author{
小島 敏之・相馬 正・小栗 紀彦 \\ 農林水産省畜産試験場 305 茨城県稲敷郡茎崎町池の台 2 \\ 筑波農林研究団地内局 私書箱 5 号
}

哺乳動物初期胚の標準的凍結保存技術 (Whittingham et al., 1972; Wilmut and Rowson, 1973; Bank and Maurer, 1974; Whittingham, 1975; Bilton and Moore, 1976; Willadsen et al., 1976; Yamamoto et al., 1982) は, 哺乳動物胚以外の細胞のそれを基本に発達してきて いる。しかし, 胚が持つ特有の性質 (Leibo, 1980), す なわち水の透過性が低く, 活性化エネルギーが大きく, 容積に対する表面積の比が小さいなどのために, いくつ かの特別な処置が必要である。冷却中に凍結媒液が過度 の過冷却状態となるのを避けるために, 細胞外液に氷晶
形成を誘起する植水 (seeding) 操作は，その重要な行程 のひとつである。

植水操作それ自体は, 非常に簡単で, 液体窒素中に予 め冷却しておいたピンセットを, 凍液媒液が入っている 容器のメニスカス部分に外側より瞬間的に接触させるこ となどは，その一方法である。ただし，その操作は手動 であるので, 再現性に欠ける危険性があり，また多本数 のサンプルを短時間で処理することは困難である。胚の 凍結保存のために商品化されているプログラム・フリー ザーには自動植氷装置が付いているものもあるが，それ 
らでは, 凍結容器の選択および凍結容器（とくに,プラス チック・ストローの場合）を植水装置に装着する方法, 凍結媒液の充垻方法に制約がある。

このような植水操作に打ける欠点を改善するため, 著 者らはヨウ化銀を用いた植水方法を考案した（Kojima et al., 1986)。ヨウ化銀分子は, 過冷却状態の水中で, また氷晶に関して過飽和状態の水蒸気中で水晶核となり 易い性質を持っており（Vonnegut，1947），そのため人 工降雨の誘起実験に使われたことがある（Hatakeyama， 1956)。このヨウ化銀の氷晶形成促進効果を胚の凍結保 存に応用することを試み, 温度センサーを装着したダミ 一・ストローの冷却試験や凍結・融解家鬼胚の体外培養 試験によって, その有効性を確認し, 従来行ってきた植 氷操作を省略しても生存肧が高率に得られることを証明 した (Kojima et al., 1986)。本試験では, この方法を 牛胚の凍結保存に応用し, その移植後の生存性を検討し た。

\section{材料と方法}

採卵と供試卵の選別 当場で飼養している黒毛和種未 経産牛の黄体期に, FSH 製剤(アントリン, デンカ製 薬）総量 $28 \mathrm{mg}$ を漸減的に 4 日間（1 日あたり朝夕の 2 回）頸部皮下に投与して多排卵を誘起し,さらに FSH 製剂投与開始後48時間目と72時間目に $\mathrm{PGF}_{2} \alpha$ 製剂（パ ナセラン, 第一製薬）を $15 \mathrm{mg}$ ずつ頸部筋肉内に投与 して発情を誘起し, 発情を発見した当日の午前中と翌日 の午前中に当場飼養の黑毛和種雄牛の新鮮精液を計 2 回 人工授精した。性周期の 7 日目（発情日を 0 日とする） に採取した胚のらち，4段階評価で A， B ランクの桑実 期〜胚盤胞期の胚を供試した。

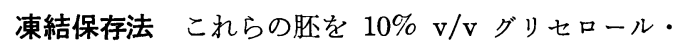
修正 PBS 溶液 (modified phosphate buffered saline solution, Whittingham, 1976)（凍結媒液）中へ移し, 冷却開始まで室温（約 $25^{\circ} \mathrm{C}$ ) に30分間 (平衡時間) 放置 した。この間に Fig. 1 の模式図に示したように, 0.25

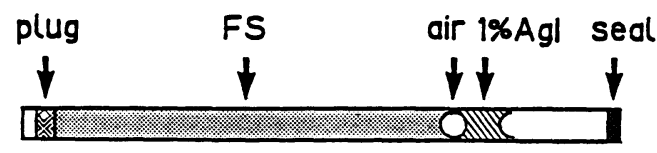

Fig. 1. Diagram of $0.25 \mathrm{ml}$ straw used in this study. $70 \mathrm{~mm}$ of $10 \% \mathrm{v} / \mathrm{v}$ glycerol containing one bovine embryo (FS), $3 \mathrm{~mm}$ of air bubble, $10 \mathrm{~mm}$ of $1 \%$ suspension of silver iodide in distilled water $(1 \%$ AgI). The straw was sealed by heat. $\mathrm{ml}$ 容量の人工授精用プラスチック・ストロー (I.M.V., フランス）内へ, 泼を含む凍結媒液（層の長さ, $70 \mathrm{~mm}$ ), 気泡 $(3 \mathrm{~mm}), 1 \%$ ヨウ化銀蒸留水䀣濁液 ( $1 \% \mathrm{AgI}$, $10 \mathrm{~mm}$ ) の順に吸引し、ストロー端を加熱して閉封した。 ストロー1本あたり 1 個の胚を納め, 液体窒素蒸気によ る気相温度制御方式のプログラム・フリーザー（ダイサ ン FFP-190, 大阪酸素工業株式会社）を用いて, 冷却 槽内の温度を室温から $-7^{\circ} \mathrm{C}$ まで $1^{\circ} \mathrm{C} / \mathrm{min}$ で冷却した 後, そのまま10分間保持した。 $-7^{\circ} \mathrm{C}$ から $-35^{\circ} \mathrm{C}$ まで $0.3^{\circ} \mathrm{C} / \mathrm{min}$ で泠却し続けた後, 液体窒素中へ浸漬し, 融 解時まで保存した。冷却途中外部からの植氷操作は行わ ずまたプログラム・フリーザーの自動植水装置も作動 させなかった。

融触および移植 移植当日に, $37^{\circ} \mathrm{C}$ の温水中へスト ローを浸漬して融解させた。融解後, ストロー内に気泡 が残っている場合には, 気泡部分を切断して $1 \% \mathrm{AgI}$ 層を切り離し, 他方気泡が消失しているストローでは, そのままそれぞれ時計血へ内容物を移した。つついて， $0.75 \mathrm{M}$ あるいは $1.0 \mathrm{M}$ ショ糖・修正 PBS 溶液中へ回 収融解肧を移し，10分間々のまま放置した。その後, 胀 を修正 PBS 溶液で洗浄し, 形態観察を行い, 人工授精 用プラスチック・ストロー内に吸引収容して移植場所へ 運搬した。自然発情の性周期 7 日目のホルスタイン種未 経産牛に 1 頭あたり 1 個の胚を, 黄体側子宮角に頸管経 由法により移植した。妊娠の成否は, 移植後50〜 60 日目 に直腸検査を実施して確認し, 受胎牛は分娩を待って産 子の状態をも観察した。

\section{結果と考察}

Table 1 に各凍結・融解胚の移植成績を示してある。 合計 7 個の胚を融解し, 延べ 7 頭の受卵牛に移植した結 果, 2 頭受胎し, それぞれ正常な雄子牛を分婏した。 H17 と H127 の妊娠期間は, 283 日と 280 日, 産子の 生時体重は $28 \mathrm{~kg}$ と $24.5 \mathrm{~kg}$ であった。著者らの家鬼 胚を用いた実験 (Kojima et al., 1986) では, ヨウ化銀 による氷晶形成誘起法が胚の凍結保存に有効であること を in vitro の発育成績から確認できたが，本試験では in vivo で牛胚の生存を指標として, この方法の有効性 を再確認した。

著者らがこの方法を応用するにあたって最も懸念した のは，ヨウ化銀の胚および子宮粘膜に対する有害作用で あったが,著者らの家鬼胚を用いた実験 (Kojima et al., 1986）および本試験の受卵牛 H17 の成績から判断して も, 現在のところ供試濃度におけるその有害作用は認め 
Table 1. Informations of donors, embryos and diluents used in the present study and the result of transfer through cervix to appropriately synchronized recipients

\begin{tabular}{|c|c|c|c|c|c|c|c|c|c|}
\hline & Donor & $\begin{array}{c}\text { Stage of } \\
\text { develop- } \\
\text { ment* }\end{array}$ & Ranking & Diluent & $\begin{array}{c}\text { Ranking } \\
\text { of frozen- } \\
\text { thawed } \\
\text { embryo }\end{array}$ & $\begin{array}{l}\text { Recipi- } \\
\text { ent }\end{array}$ & Pregnancy & Parturition & Offspring \\
\hline 1 & B 8 & B & A & $1.0 \mathrm{M}-\mathrm{suc} \S$ & $A \#$ & $\mathrm{H} 17$ & + & + & $\begin{array}{c}\text { male } \\
(28 \mathrm{~kg})\end{array}$ \\
\hline 2 & B 8 & E B & B & $0.75 \mathrm{M}-\mathrm{suc}$ & B & H 159 & - & - & - \\
\hline 3 & B 8 & M & A & $1.0 \mathrm{M}$-suc & A & H 159 & - & - & - \\
\hline 4 & B 134 & E B & A & $1.0 \mathrm{M}-\mathrm{suc}$ & $\mathrm{B}$ \#\# & H21 & - & - & - \\
\hline 5 & B 134 & E B & B & 1. $0 \mathrm{M}$-suc & B & H21 & - & - & - \\
\hline 6 & B 12 & M & A & $1.0 \mathrm{M}$-suc & B & H 125 & - & - & - \\
\hline 7 & B 12 & M & B & $1.0 \mathrm{M}$-suc & B & $\mathrm{H} 127$ & + & + & $\begin{array}{c}\text { male } \\
(24.5 \mathrm{~kg})\end{array}$ \\
\hline
\end{tabular}

* “B” means blastocyst, “EB", early blastocyst and "M", morula.

$\S$ "suc" means sucrose.

\# An air bubble intervened between the freezing solution (10\% v/v glycerol) and suspension of silver iodide has disappeared during thawing.

\# A small crack was observed in the zona pellucida.

られていない。受卵牛 H17 に移植された胚が納められ ていたストローでは, 気泡が融解後に消失しており, 肧 を含む凍結媒液と $1 \% \mathrm{AgI}$ が混合していたにもかかわ らず，受卵牛は正常な子牛を分婏した。ただし，この場 合, 胚や子宮粘膜に高濃度のヨウ化銀を作用させていな いので, この問題は今後の重要な検討課題であろう。

ストロー中の $1 \% \mathrm{AgI}$ 層は, $-2 \sim 3^{\circ} \mathrm{C}$ 付近で自然に 水結するので（Kojima et al., 1986), 凍結媒液の温度 がその凍結点温度に達すると, 自動的に $1 \%$ AgI 層の 水晶が気泡を越えて凍結媒液の氷晶形成を誘起するもの でないかと考えられる。したがって, 外部からの植水操 作は全く不要で, 温度変動の非常に少ない状況で細胞外 液に氷晶を作ることができる。また，1\% AgI と凍結媒 液を冷却するに先だって予め混合しておいても, 水晶形 成誘起効果が発揮されることが知られているので（Kojima et al., 1986), ストロー以外の 凍結容器にもこの 方法は応用できるのではないかと考えられる。その場 合, 泼周囲のヨウ化銀の微小な水晶核から氷晶形成が起 きると推測されるので, 冷却中の肧の微細環境が, 従来 の植水方法を用いた場合と異なるものと推察される。冷 却中の胚の微細環境を制御あるいは調節することによっ て透明带の損傷を防ぐことができる可能性が考えられ (Seidel, 1984), ヨウ化銀による氷晶形成誘起法は, こ の方面の研究にも応用できるものであろう。

\section{謝辞}

本論文を御校閲くださいました当場繁殖部長花田章博
士にまた有益な御助言をいただきました岡山県酪農試 験場技師野上与志郎氏にそれぞれ深甚の謝意を表しま す。文献の収集に際しまして御協力いただきました運輸 省気象研究所資料課の皆様に厚く御礼を申し上げます。

\section{References}

Bank H, Maurer RR (1974) Survival of frozen rabbit embryos. Exp Cell Res 89: 188-196.

Bilton RJ, Moore NW (1976) In vitro culture, storage and transfer of goat embryos. Aust J Biol Sci 29: $125-129$.

Hatakeyama $H$ (1956) Report of rain-making in Japan, 1954-1956. In: Papers in Meteorology and Geophysics, VII: $327-349$.

Kojima T, Soma T, Oguri N (1986) Effect of silver iodide as an ice inducer on viability of frozenthawed rabbit morulae. Theriogenology 26: 341352.

Leibo SP (1981) Preservation of ova and embryos by freezing. In: New Technologies in Animal Breeding (Brackett BG, Seidel GE.Jr, Seidel SM eds.), Academic Press, New York. pp 127-139.

Seidel GE.Jr (1984) Future research in cryopreservation of embryos. In: Techniques for Freezing Mammalian Embryos, Short Course Proceedings, Animal Reproduction Laboratory, Colorado State University. pp 95-97.

Vonnegut B (1947) The nucleation of ice formation by silver iodide. J Appl Physiol 18: 593-595.

Whittingham DG, Leibo SP, Mazur P (1972) Survival of mouse embryos frozen to $-196^{\circ} \mathrm{C}$ and $-269^{\circ} \mathrm{C}$. Science 178: 411-414. 
Whittingham DG (1975) Survival of rat embryos after freezing and thawing. J Reprod Fert 43: 575-578.

Whittingham DG (1976) General aspects of egg culture and preservation. In: Egg Transfer in Cattle (Rowson LEA ed.), Comm Eur Commun Publ, Luxembourg. pp 101-116.

Willadsen SM, Polge C, Rowson LEA, Moor RM (1976) Deep freezing of sheep embryos. J Reprod Fert 46: 151-154.
Wilmut I, Rowson LEA (1973) Experiment on the low-temperature preservation of cow embryos. Vet Rec 92: 686-690.

Yamamoto Y, Oguri N, Tsutsumi Y, Hachinohe Y (1982) Experiments in the freezing and storage of equine embryos. J Reprod Fert (Suppl) 32: 399-403.

\section{要 約}

本試験では, ヨウ化銀を用いた氷晶形成誘起法を牛胚の凍結保存に応用し, 受卵牛への移植後の生

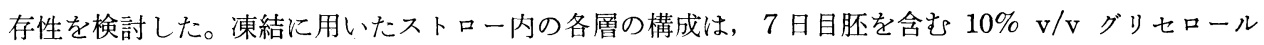
溶液 $(70 \mathrm{~mm})$, 気泡 $(3 \mathrm{~mm}), \exists ウ$ 化銀層 $(10 \mathrm{~mm})$ で, 常法に従い冷却したが, 外部からの植氷は 行なわなかった。急速融解後, $0.75 \mathrm{M}$ あるいは $1.0 \mathrm{M}$ ショ糖溶液に肧を10分間浸漬してグリセロー ルを除去した後, それらを移植に供した。7 個の拨を延べ 7 頭の受卵牛に移植し， らち 2 頭がそれぞ れ正常な雄子牛を分婏した。 